\title{
BALANCING EMPLOYER POLICIES AND EMPLOYEE RIGHTS: THE ROLE OF LEgISLATION IN ADDRESSING WorkPlace Alcohol and Drug Testing Programs
}

\author{
CLARISSA PEARCE*
}

\begin{abstract}
Workplace alcohol and drug policies create tension between employer safety interests and employee privacy rights. Despite numerous legal challenges, the appropriate balance between employer and employee interests has not yet been decided. This lack of clarity is apparent in the various policies of employers, human rights commissions, and the rights asserted by affected employees. The article examines "model" policies of the petroleum and construction sectors and analyzes jurisprudence surrounding various forms of alcohol and drug testing, keeping the distinction between union and non-union approaches. It points to a lack of cohesion in jurisprudence and alcohol and drug testing policy models, and urges the implementation of legislation for greater certainty in the field.
\end{abstract}

\begin{abstract}
Les politiques sur l'alcoolisme et la toxicomanie au travail créent des tensions entre les intérêts de sécurité des employeurs et le droit à la protection de la vie privée des employés. Malgré les nombreuses difficultés juridiques, l'équilibre approprié entre les intérêts de l'employeur et ceux de l'employé n'a pas encore été déterminé. Le manque de clarté est apparent dans les diverses politiques des employeurs, des commissions des droits de la personne et des droits revendiqués par les employés touchés. L'article examine les politiques «modèles » des secteurs du pétrole et de la construction, et analyse la jurisprudence sur les diverses formes de dépistage d'alcool et de drogue, tout en maintenant la distinction entre les approches syndicales et nonsyndicales. L'article attire l'attention sur le manque de cohésion entre la jurisprudence et les politiques modèles de dépistage d'alcool et de drogue et recommande la mise en œuvre d'une législation en vue d'une plus grande certitude dans ce domaine.
\end{abstract}

\section{TABLE OF CONTENTS}

I. INTRODUCTION . . . . . . . . . . . . . . . . . . . . . . . . . . . . . . . . . 142

II. The Use of Alcohol AND DRUg Testing

IN THE WorkPLACE . . . . . . . . . . . . . . . . . . . . . . . . . . 144

III. Legal Challenges to THE USE

of Alcohol ANd Drug Testing $\ldots \ldots \ldots \ldots \ldots \ldots \ldots \ldots . \ldots \ldots$

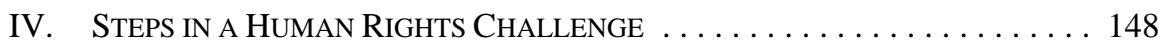

A. PRima Facie CASE of Discrimination $\ldots \ldots \ldots \ldots \ldots \ldots \ldots 148$

B. Bona Fide Occupational Requirement . . . . . . . . . . . 148

V. THE JURISPRUDENCE SURROUNDING

Alcohol And DRUg TeSting . . . . . . . . . . . . . . . . 150

A. Perceived Disability $\ldots \ldots \ldots \ldots \ldots \ldots \ldots \ldots \ldots \ldots \ldots \ldots$

B. Reasonable Cause and Post-InCident Testing $\ldots \ldots \ldots \ldots . . .154$

C. RANDOM TESTING . . . ....................... 156

D. Advances in Drug Testing Technology $\ldots \ldots \ldots \ldots \ldots \ldots 161$

E. Pre-employment Drug Testing $\ldots \ldots \ldots \ldots \ldots \ldots \ldots \ldots \ldots$

F. Pre-AcCess Testing $\ldots \ldots \ldots \ldots \ldots \ldots \ldots \ldots \ldots \ldots$

G. THE EXTENT OF THE EMPLOYER'S OBLIGATIONS

to EMPLOYeEs Who Test Positive . . . . . . . . . . . . . . . . . . . 164

VI. LEgisLATION ................................ 166

B.A. (Hon.) (2004), LL.B. (2007). Clerked with the Alberta Court of Queen's Bench, completed articles with Macleod Dixon LLP, Calgary, Alberta. 


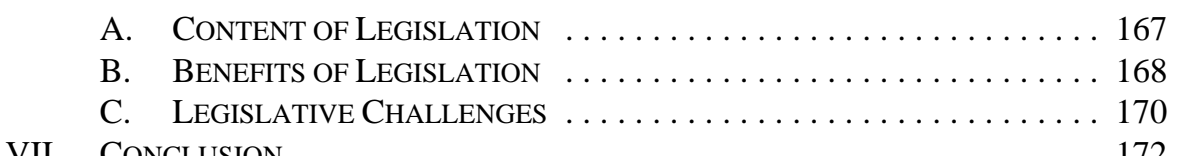

\section{INTRODUCTION}

In any society the rights of one will inevitably come into conflict with the rights of others. It is obvious then that all rights must be limited in the interest of preserving a social structure in which each right may receive protection without undue interference with others. This will be especially important where special relationships exist, in the case at bar the relationship of employer and employee. ${ }^{1}$

The employer and employee relationship often involves a search for the appropriate balance between conflicting interests. This search is often difficult, given the diverse array of legislation, jurisprudence, and contractual relationships that underpin and affect the workplace. The difficulty of finding an appropriate balance between employer and employee interests is reflected in the contentious issue of the implementation of workplace alcohol and drug policies. In Alberta, under the Occupational Health and Safety Act, employers are required to provide a safe workplace for all employees. ${ }^{2}$ Likewise, Albertan employers, like all Albertans, are required to comply with the Alberta Human Rights, Citizenship and Multiculturalism Act and to provide a workplace free from discrimination. ${ }^{3}$ Employers of union employees are required to comply with the terms of the governing collective agreement, and employers of non-union employees are required to comply with common law principles of employment law. The inherent difficulty arises when these objectives come into conflict. Such a conflict is often alleged in the case of employment alcohol and drug testing.

Employer alcohol and drug policies seek to prevent employee impairment on the job site, thus preventing accidents that could be costly in personal, financial, and environmental terms. Employers assert that the goal of improving workplace safety provides a sufficient justification for the implementation of workplace alcohol and drug testing policies. However, such policies have been the subject of legal challenge by employees. Employees may challenge the implementation of the policy generally, specific aspects of the policy, or the discipline of an employee as a result of his or her failure to adhere to the policy. Such challenges generally take place in one of two forums, depending on whether the workplace is unionized. In union environments, an employee may make a grievance that the employer's actions are contrary to the collective agreement or in excess of management rights. In nonunion environments, employees often bring forward a human rights complaint alleging that the policy is discriminatory.

Despite the significant number of legal challenges that have been raised in response to the implementation of workplace alcohol and drug testing policies, the law in this area has not yet conclusively answered the question of the appropriate balance between employer and employee interests. This lack of clarity is reflected in the disagreements and inconsistencies 
that currently exist between the policies of various employers, the policies of the Canadian Human Rights Commission (CHRC) and the Alberta Human Rights and Citizenship Commission (AHRCC), and the rights asserted by affected employees. This lack of clarity can be attributed to the complexity of alcohol and drug policies and the varied workplaces they are applied to. A typical alcohol and drug policy may contain a number of different components, including pre-employment testing, random testing, reasonable cause testing (testing following reasonable suspicion of employee impairment), post-incident testing (testing following a workplace accident), pre-access testing (testing of employees or contractors entering a job site), or mandatory disclosure (requiring employees to disclose prior addictions). The workplaces in which alcohol and drug policies are introduced vary widely. For example, such policies are introduced in both union and non-union environments. However, the considerations in arbitral jurisprudence may not be relevant in human rights jurisprudence. Furthermore, the factual circumstances surrounding the introduction of the policy and its breach may vary widely. These varied scenarios make it difficult for the jurisprudence in this area to mature to the point where employers can be certain about the legality and the limits of their alcohol and drug policy.

To provide guidance and greater certainty to employers, some industries have developed "standard" alcohol and drug testing policies. The Canadian Upstream Petroleum Industry (CUPI) and the Construction Owners Association of Alberta (COAA) have each issued industry-specific guidelines setting out appropriate alcohol and drug policies. ${ }^{4}$ The CUPI guidelines are generally implemented in non-union environments, whereas the Canadian Model guidelines generally apply to union environments. However, these guidelines have not been adopted by every employer in these industries. Furthermore, questions remain about the legality of portions of these policies. Certain aspects of the model policies conflict with the stated policy of the CHRC and the AHRCC, and unions continue to oppose aspects of the Canadian Model.

In this article, I will begin by discussing the use of alcohol and drug testing in the workplace. I will then give an overview of the typical challenges that employees raise in response to the imposition of these policies. I will go on to review the relevant jurisprudence to determine the current law surrounding testing policies and to identify uncertainties and inconsistencies that remain. Given this jurisprudence, I will argue that the most appropriate means to achieve a balance between employer and employee interests is through the implementation of government legislation. This would particularly benefit non-union workers whose interests are not protected by a collective agreement. It would be possible to extract much of the content of such legislation from the established case law principles, the CUPI and the COAA models, and recognition of the underlying objectives of the HRCMA. I will also identify the challenges associated with the implementation of legislation, including

4 Enform, “Alcohol and Drug Policy Model for the Canadian Upstream Petroleum Industry” (September 2007), online: ENFORM <http://www.enform.ca/assets/files/canadian_upi_model_final_july_2007. pdf> [CUPI Model]; Construction Owners Association of Alberta, “Canadian Model for Providing a Safe Workplace: A best practice of the Construction Owners Association of Alberta: Alcohol and Drug Guidelines and Work Rule" (October 2005), online: COAA <http://www.coaa.ab.ca/BEST PRACTICES/Safety/Canadian ModelforProvidingaSafeWorkplace/tabid/71/Default.aspx $>$ [Canadian Model]. 
conformity with the Canadian Charter of Rights and Freedoms, ${ }^{5}$ adaptation to scientific advancements, and consultation with employers and employees.

\section{The Use Of Alcohol AND DRUg TeSting IN THE WORKPLACE}

The prevalence of workplace alcohol and drug testing programs has increased exponentially over the last few years. In 2005, alcohol and drug testing was used in 8 percent of workplaces in Alberta, compared to 1 percent of workplaces in $1992{ }^{6}$ The reason for the increase can be tied to employer concerns about productivity, liability, and safety. According to the Alberta Alcohol and Drug Abuse Commission, "[a]lcohol and drug [abuse] costs Alberta business and industry more than $\$ 400$ million every year in lost productivity."7 These costs include the "increased risk of injury, depression, stress, reduced morale, increased absenteeism, and higher workers' compensation and insurance costs." ${ }^{8}$ Further, the liability that employers may face in the event of a large-scale workplace accident caused by employee impairment is great. For example, following the Exxon Valdez oil spill disaster, which was contributed to in part by intoxicated employees, Exxon paid US\$2 billion in cleanup costs and was subject to litigation regarding further payment of millions of dollars in punitive damages. $^{9}$

Further, aside from a purely cost-oriented analysis, employers are subject to a legal obligation to ensure the safety of their employees. Section 2(1) of the OHSA requires:

Every employer shall ensure, as far as it is reasonably practicable for the employer to do so,

(a) the health and safety of

(i) workers engaged in the work of that employer. ${ }^{10}$

This imposes a positive obligation on employers to address workplace safety, and many employers argue that in order to fully discharge this obligation it is necessary for them to implement some sort of alcohol and drug testing policy.

Concerns about safety have particular salience in the petroleum and construction industries. The petroleum industry is one of the most vocal and active in establishing workplace alcohol and drug testing policies and this is likely due to the nature of the industry itself. ${ }^{11}$ First, the industry employs a large number of young and inexperienced workers, who are at a statistically higher likelihood of abusing alcohol and drugs. ${ }^{12}$ Second, the wages in the oil and gas industry are very high, with the average wage in Fort McMurray, Alberta

Part I of the Constitution Act, 1982, being Schedule B to the Canada Act 1982 (U.K.), 1982, c. 11 [Charter].

Conrad McCallum, “Random Roughshod” OHS Canada 21:7 (October/November 2005) 30 at 31. Ibid.

Ibid.

Gulf Coast Industrial Workers Union v. Exxon, 991 F.2d 244 (5th Cir. 1993).

Supra note 2.

Supra note 6.

Patricia MacInnis, “Lone Ranger takes on Canada's Drug-Toting Cowboys” Canadian Occupational Safety 44:1 (January/February 2006) 20, online: Canadian Occupational Safety <http://www.cbp.ca/ eventspages/PDF/KRW07/W2_COS_Ranger.pdf >. 
being CDN\$91,000 in 2006. ${ }^{13}$ Third, employees are often living in work camps, away from their traditional social supports, and with little source of entertainment. This combination of factors leads to a high risk of substance abuse, and indeed, the Fort McMurray area is "rife with substance abuse." 14 This high risk is combined with working conditions that are particularly dangerous. ${ }^{15}$ These factors have led most employers in the petroleum industry to adopt testing policies and, given their growing prevalence as an industry standard, remaining employers are under pressure to adopt conforming policies. ${ }^{16}$

Similar concerns apply to the construction industry, which, in contrast to the petroleum industry, is typically made up of a unionized workforce. In United Association of Journeymen and Apprentices of the Plumbing and Pipefitting Industry of the United States and Canada, Local 488 v. Bantrel Constructors, the Court accepted that of all Canadian workplaces, construction sites have the highest workplace use of illicit drugs. ${ }^{17}$

The introduction of alcohol and drug testing policies into these workplaces is part of an effort to combat the safety risks associated with workplace impairment. The success of such policies in reducing impairment is difficult to determine. This is, in part, because of the difficulty in obtaining accurate information about the level of substance use in a workforce prior to the implementation of testing. This is also due to the fact that companies typically introduce alcohol and drug testing policies as one portion of a larger program to combat alcohol and drug abuse. It is, therefore, difficult to isolate the extent to which reduced levels of impairment is due to the testing itself or due to increased education and the availability of treatment programs. Perhaps because of such limitations, there has been no demonstrated causal link between workplace alcohol and drug testing programs and decreases in workplace accidents. $^{18}$

There is, however, circumstantial evidence indicating the success of alcohol and drug testing policies. In a study of American companies that implemented alcohol and drug testing programs, many companies subsequently experienced a sharp decrease in the percentage of positive tests. ${ }^{19}$ One company included in the study, Southern Pacific Railroad, had the number of positive tests decrease from 22.9 percent to 5.8 percent in three years and the number of personal injuries decrease from 15.5 per 200,000 worker hours to 5.8 worker hours per 200,000 over five years. Another company, IMC fertilizer, also implemented an alcohol and drug testing policy as part of its overall substance abuse plan. After five months, their accident rate had dropped from 8.2 worker hours per 200,000 to 3.9 worker hours per $200,000 .^{20}$

\footnotetext{
13 Ibid. at 22, quoting Murray Sunstrum.

Ibid. at 20.

Ibid.

Supra note 6 at 35.

2007 ABQB 721, 431 A.R. 314 at para. 22 [Bantrel].

Julie A. Godkin, “Employee Drug Testing: Orwellian Vision or Pragmatic Approach to Problems in the Workforce” (2000) 9 Dal. J. Leg. Stud. 188 at 194-95.

19 Howard Moyer, “Ontario Law Reform Commission's Report on Drug and Alcohol Testing in the Workplace: A Critique” (1994) 2 Canadian Labour Law Journal 534 at 540.

Ibid. at 540 .
} 
The debate about the efficacy of alcohol and drug testing policies provides a critical contextual backdrop to the debate surrounding alcohol and drug testing programs. In the 2002 Canadian Human Rights Commission Policy on Alcohol and Drug Testing (which is currently under review), the CHRC states: "Canadian human rights law takes a different approach to the U.S. on the issue [of] drug testing — not because protecting the rights of those who abuse drugs or alcohol is considered more important than public safety, but because drug testing has not been shown to be effective in reducing drug use, work accidents or work performance problems." ${ }^{21}$ However, given the extensive resources that employers invest in the development and implementation of testing programs, it is clear that they are perceived to be of some benefit — not only for detecting actual impairment, but also for their deterrent effect.

\section{Legal Challenges to the Use of Alcohol AND DRUg Testing}

The implementation of alcohol and drug testing policies has been met with considerable employee opposition. Such opposition is rooted primarily in human rights concerns, privacy considerations, and employee rights.

The nature of the opposition to testing policies and the arguments available to employees varies depending on whether the policy has been implemented in a union or non-union environment. In a union environment, employees have a far broader basis upon which to grieve the implementation of a policy generally or its application to them specifically. While it is now generally accepted that it is a right of management to implement an alcohol and drug testing policy, ${ }^{22}$ it is open to the union to grieve aspects of that policy as being in excess of management rights. In doing so, unions can raise arguments about employee privacy and the efficacy of testing. Employees who are disciplined pursuant to a workplace policy also have a variety of arguments open to them in grieving the discipline. An improper investigation, a failure to follow the policy, a failure to show just cause in a case of dismissal, and exceeding the limits of management rights may all provide the basis for a successful challenge of a workplace alcohol and drug policy. Arbitral decisions often contain discussions of Canadian values, the need to balance employee privacy with an employer's need to ensure workplace safety, and the limits on the ability of employers to intrude into the personal lives of their employees.

The options for non-union employees wishing to legally challenge a workplace alcohol and drug policy are significantly more limited. The vast majority of these challenges take place under the applicable human rights legislation (which also applies to union employees and may be considered in an arbitration). The Canadian Human Rights Act ${ }^{23}$ applies to federal employers, and the HRCMA applies to provincial employers in Alberta. Other provinces have similar legislation. Although the wording between human rights acts may

21 Canadian Human Rights Commission Policy on Alcohol and Drug Testing (Ottawa: Canadian Human Rights Commission, 2002) at 11, online: CHRC <http://www.chrc-ccdp.ca/pdf/poldrgalceng.pdf>.

22 DuPont Canada v. Communications, Energy Paperworkers Union of Canada, Local 28-0 (2002), 105 L.A.C. (4th) 399 (OLA).

23 R.S.C. 1985, c. H-6 [CHRA]. 
differ, the Supreme Court has held that interpretations should be consistent across jurisdictions. $^{24}$

These acts prohibit discrimination on a prohibited ground. Under s. 3(1) of the CHRA, disability, which is specifically defined as including "previous or existing dependence on alcohol or a drug," constitutes a prohibited ground of discrimination. ${ }^{25}$ This makes it unlawful for an employer to refuse to employ or continue to employ a worker dependent on alcohol or drugs, ${ }^{26}$ or to deprive such workers of employment opportunities. ${ }^{27}$ One exception to this general protection is if an employer can establish that a refusal to employ or a deprivation of opportunities is in accordance with a bona fide occupational requirement and to accommodate the employee would constitute undue hardship. ${ }^{28}$

The HRCMA contains similar provisions prohibiting discrimination based on a disability, except on the basis of a bona fide occupational requirement. ${ }^{29}$ Unlike the $C H R A$, the HRCMA does not explicitly include alcohol or drug dependence within its definitions of mental or physical disability. ${ }^{30}$ Nonetheless, in keeping with the Supreme Court's direction to interpret human rights legislation consistently, alcohol and drug dependence has now been judicially recognized as a disability in Alberta under the HRCMA, as well as in every other jurisdiction in Canada. ${ }^{31}$

The use of human rights legislation to challenge workplace alcohol and drug policies has significant limitations. Human rights legislation protects people who are suffering from the disability of addiction from discrimination. However, many people who use alcohol and drugs are "casual users" not suffering from a disability. These employees often object to the implementation of alcohol and drug policies on the basis of privacy concerns. This is often on the basis that drug testing policies not only monitor impairment at the workplace, but also off the workplace. Most forms of drug testing, including urinalysis, do not measure present impairment; rather, they measure the presence of drug metabolites in the body. Drugs may have been ingested outside of working hours and be causing no present impairment. In the case of marijuana, actual impairment may have taken place three or four weeks ago outside of work hours. Thus, such testing goes against the traditional notion that "what workers do in their off-hours is their own business." ${ }^{\text {,2 }}$

However, notwithstanding their privacy concerns, unless employees can show that they are suffering from a disability, the protection of human rights legislation does not apply to them. Employees have attempted to get around this limitation by arguing that by disciplining

University of British Columbia v. Berg, [1993] 2 S.C.R. 353; Quebec (Commission des droits de la personne et des droits de la jeunesse) v. Montréal (City of), 2000 SCC 27, [2000] 1 S.C.R. 665 [Quebec].

Supra note 23, ss. 3(1), 25.

Ibid., s. 7.

Ibid., s. 10.

Ibid., s. 15.

Supra note 3, s. 7(3).

Ibid., ss. 44(1)(h), 44(1)(l).

Geoffrey England, Roderick Wood \& Innis Christie, Employment Law in Canada, 4th ed., looseleaf, Vol. 1 (Markham, Ont.: LexisNexis, 2005) at para. 5.127.

Supra note 6 at 35. 
them for testing positive on an alcohol and drug test, the employer "perceives" them to be suffering from a disability, and thus, they are entitled to the protection of human rights legislation. However, as will be discussed below, the recent decision of the Alberta Court of Appeal in Alberta (Human Rights and Citizenship Commission v. Kellogg Brown \& Root (Canada) $)^{33}$ seems to have severely restricted the ability of employees to argue "perceived disability." Thus, non-addicted employees who wish to legally challenge workplace alcohol and drug policies are left with limited options. Challenges under the provincial or federal privacy acts are an option, but the majority of employees will have consented to tests as a condition of their employment. Furthermore, even if a privacy violation is established, the remedies are typically limited.

\section{STEPS IN A Human Rights Challenge}

For those employees who do choose to proceed with a human rights complaint, alleging discrimination on the basis of alcohol or drug dependence, the courts follow a standard approach accepted and applied in all human rights jurisprudence. First, the employee must establish that the application of the workplace policy is prima facie discriminatory. Then the burden shifts to the employer to justify the standard as a bona fide occupational requirement.

\section{A. Prima Facie Case of Discrimination}

To establish a prima facie case of discrimination, an employee must show that the application of the alcohol and drug policy constitutes discrimination on the basis of a prohibited ground (here, alcohol or drug dependence) under s. 7 of the CHRA or under s. 7 of the HRCMA in Alberta. The onus is on the employee to establish discrimination on a balance of probabilities in a manner that is "complete and sufficient to justify a verdict in the complainant's favour in the absence of an answer from the respondent-employer.” ${ }^{34}$

\section{B. BONA FIDE OCCUPATIONAL REQUIREMENT}

Once a prima facie case of discrimination has been established, the burden shifts to the employer to establish, also on a balance of probabilities, that the prima facie discriminatory standard is a bona fide occupational requirement (BFOR) under s. 15 of the CHRA or under s. 7(3) of the HRCMA.

The accepted approach for determining whether a policy constitutes a BFOR was set out in British Columbia (Public Service Employee Relations Commission) v. BCGSEU ${ }^{35}$ and British Columbia (Superintendent of Motor Vehicles) v. British Columbia (Council of Human Rights). ${ }^{36}$ This approach is used in all of the alcohol and drug testing cases decided under the human rights legislation after 1999. Meiorin requires employers to "accommodate the characteristics of affected groups within their standards, rather than maintaining 
discriminatory standards supplemented by accommodation for those who cannot meet them.”37 Using this approach, to establish a BFOR, the employer must prove:

(1) [T]hat the employer adopted the standard for a purpose rationally connected to the performance of the job;

(2) that the employer adopted the particular standard in an honest and good faith belief that it was necessary to the fulfilment of that legitimate work-related purpose; and

(3) that the standard is reasonably necessary to the accomplishment of that legitimate work-related purpose. To show that the standard is reasonably necessary, it must be demonstrated that it is impossible to accommodate individual employees sharing the characteristics of the claimant without imposing undue hardship upon the employer. ${ }^{38}$

The first stage of the Meiorin test is an objective one. In the context of workplace alcohol and drug testing, it has been established that increasing safety is a purpose rationally connected to the performance of the job. ${ }^{39}$

The second stage is subjective. It seeks to evaluate whether the standard was put in place with the intention of discriminating. No alcohol or drug testing policy challenged in Canada has failed at this stage.

The third stage of the Meiorin test is typically the most contentious. The employer must establish two things at this stage. First, the employer must show that the standard is reasonably necessary to achieve the objective set out in step one. If successful, the employer must then establish that accommodating an employee would result in undue hardship. As McLachlin J. (as she then was) points out in Meiorin, accommodation to the point of undue hardship is a high standard. She quotes Sopinka J., stating that

\footnotetext{
'[t]he use of the term "undue" infers that some hardship is acceptable; it is only "undue" hardship that satisfies this test.' It may be ideal from the employer's perspective to choose a standard that is uncompromisingly stringent. Yet the standard, if it is to be justified under the human rights legislation, must accommodate factors relating to the unique capabilities and inherent worth and dignity of every individual, up to the point of undue hardship. ${ }^{40}$
}

If the employer is able to establish accommodation to the point of undue hardship, then the complaint is dismissed. 


\section{The Jurisprudence Surrounding Alcohol AND Drug Testing}

Although courts and tribunals have consistently followed the Meiorin approach when considering human rights issues relating to workplace alcohol and drug policies, this application has not resulted in a clear delineation of the appropriate balance between employer interests and employee rights. The courts have largely declined to enunciate general principles that apply to the arena of alcohol and drug testing as a whole. Rather, the decisions deal with specific aspects of policies: the type of testing (alcohol or drug, and the scientific method used), when the testing occurs (pre-employment, random, post-incident, reasonable cause, and pre-access), and who makes the complaint (those suffering from a dependency or casual users). The extent to which the principles enunciated with regard to one of these aspects being applicable to another aspect is often unclear.

In this section, I will review the existing jurisprudence in a number of significant areas: the issue of perceived disability, reasonable cause and post-incident testing, random testing, and pre-employment testing. I will note the stated policies of the $\mathrm{CHRC},{ }^{41}$ the AHRCC, ${ }^{42}$ the CUPI guidelines, ${ }^{43}$ the COAA guidelines, ${ }^{44}$ and highlight any inconsistencies between these policies and the prevailing jurisprudence. Within this discussion, I will note some of the scientific advances in the area of drug testing and the effect that such advances may have on the legality of alcohol and drug testing policies.

One of the landmark decisions in establishing the current jurisprudential approach to human rights complaints dealing with workplace alcohol and drug testing is the Entrop decision. ${ }^{45}$ Unlike most decisions in this area, which are limited to a specific aspect of a given policy, Entrop dealt with pre-employment testing, post-incident testing, random testing, reasonable cause testing, and mandatory disclosure. Entrop is significant both because it was an Ontario Court of Appeal decision that offered a comprehensive analysis of a number of elements of a typical testing policy and because it was the first major decision to follow the Meiorin analysis. In Entrop, the employer, Imperial Oil, instituted a comprehensive workplace alcohol and drug policy for the purpose of improving safety. In addition to the testing portions of the policy, it also required all employees to disclose any prior involvement with alcohol and drugs. Mr. Entrop, the employee who initiated the complaint, had previously suffered from alcoholism but had been sober for the last seven years. As required by the workplace policy, he disclosed his prior alcoholism. He was immediately removed from his position and transferred to what he considered to be a less desirable position.

Although Entrop's complaint related only to the portion of the policy dealing with mandatory disclosure, the Human Rights Tribunal considered all elements of the policy. The Court of Appeal criticized this as beyond the tribunal's jurisdiction, but because the issues

Alberta Human Rights and Citizenship Commission, "Drug and alcohol testing: Information Sheet" (August 2004), online: Alberta Land Surveyors’ Association <http://www.alsa.ab.ca/pdf/Member Resources/Safety/drug_alcohol.pdf>.

$43 \quad$ CUPI Model, supra note 4.

44 Canadian Model, supra note 4.

$45 \quad$ Supra note 39. 
had already been argued, it went on to consider the remainder of the policy. It has been argued that the lack of a factual basis for the challenge to the testing portions of the Imperial Oil Policy weakened the precedential value of the Court of Appeal's findings. However, while the decision may be criticized on this basis, Entrop continues to be cited frequently by the courts and human rights tribunals and the approach that it sets out is closely followed. In the discussion of the various aspects of testing policy jurisprudence below, Entrop often forms the foundation for the approach governing that form of testing.

\section{A. Perceived Disability}

For employees making a human rights complaint, a precursor to a challenge to the policy (and the judicial analysis of the policy itself) is establishing that discrimination has occurred. To do so, the employee must fall within one of the prohibited grounds of discrimination. In the context of alcohol and drugs, the relevant ground of discrimination is physical disability, on the basis of addiction. The challenge for employees seeking to contest the application of a workplace alcohol and drugs policy is that the majority of people who use alcohol and drugs are "casual" or "recreational" users and are not, in fact, addicted. In the lower court decision of Chiasson, the Court accepted that 90 percent of marijuana users do not suffer from a disability. ${ }^{46}$

To avoid immediate dismissal of their complaint, in the past such employees have successfully argued that they nonetheless fall under the jurisdiction of the human rights act, because by disciplining or dismissing them for their substance use, the policy treats them as though they are addicted. These employees argue that they are suffering from a perceived disability.

The first significant analysis of the concept of perceived disability took place in Entrop. As Entrop had not used alcohol or drugs in the past seven years and was no longer suffering from an addiction, the Ontario Court of Appeal held that he was not suffering from a disability under the Human Rights Code. ${ }^{47}$

However, the Imperial Oil alcohol and drug policy defined substance abusers to include "experimenters" and "recreational users." 48 Thus, the Court concluded that "though the social drinker and casual drug user are not substance abusers and, therefore, not handicapped, Imperial Oil believes them to be substance abusers for the purpose of the policy." 49 Under the ONHRC, perceived substance abusers are explicitly provided protection from discrimination. ${ }^{50}$ Thus, prima facie discrimination was made out, although Entrop himself was not suffering from a disability at the time of his complaint.

Entrop was subsequently cited as authority for the argument that non-addicted users of alcohol or drugs are protected under the human rights legislation on the basis of perceived disability. However, the workplace policy in Entrop can be distinguished from most other

Supra note 33 .

R.S.O. 1990, c. H.19 [ONHRC].

Supra note 39 at para. 90 .

Ibid. at para. 92.

Ibid. at para. 87, citing ONHRC, supra note 47, s. 5(1). 
workplace policies in that it explicitly classified casual users as substance abusers. This serves to limit the precedential value of Entrop as it relates to the concept of perceived disability.

In the jurisprudence following Entrop, there was some conflict surrounding what constitutes a "perceived” disability. In Halter v. Ceda-Reactor Limited, an entire work crew was subjected to what was determined to be a random alcohol and drug test following a bar fight between two employees. ${ }^{51}$ In both this and a subsequent follow-up test, Mr. Halter tested positive for marijuana and was ultimately dismissed. Halter denied that he suffered from a disability. However, the Tribunal concluded that Ceda-Reactor made no efforts to determine his individual level of dependency and that the test was administered on the basis that all employees were perceived to be potential substance abusers. ${ }^{52}$ Furthermore, the Tribunal held that after testing positive, Halter was "further perceived" to be a substance abuser, and thus the tribunal had jurisdiction under the HRCMA. ${ }^{53}$

Perceived disability was also found in Alberta (Human Rights and Citizenship Commission) v. Elizabeth Métis Settlement. ${ }^{54}$ This decision dealt with an Alberta reserve struggling with severe addiction issues. The band council passed a resolution approving alcohol and drug testing for settlement employees who were perceived by the community to be substance users. In Elizabeth Métis, the Court of Queen's Bench considered the issue of perceived disability in Alberta and observed that, unlike the ONHRC (under which Entrop was decided), the HRCMA does not expressly prohibit "perceived" discrimination. ${ }^{55}$ Nonetheless, Elizabeth Métis stresses the importance of a broad and inclusive interpretation of the HRCMA, noting that "mere differences in terminology do not support a conclusion that there are fundamental differences in the objectives of human rights statutes." 56 The Court concluded that "an employee who loses her job for refusing to undergo random drug and alcohol testing, being treated in the same fashion as if she was an alcoholic or addict, is entitled to the protection of s. 7(1) of the Act." 57

This decision was subsequently overturned by the Court of Appeal on the basis that the lower court had neglected to determine the prerequisite issue of whether the workplace alcohol and drug policy applied to the employees. ${ }^{58}$ This, and the fact that Elizabeth Métis considers a unique factual circumstance (a remote community struggling to address alcohol and drug addiction), makes this finding of perceived disability of little persuasive value.

Further, although Halter and Elizabeth Métis conclude that human rights jurisdiction was established on the basis of perceived disability, the preponderance of decisions following Entrop conflict with that conclusion. The British Columbia Human Rights Tribunal's

51 (16 May 2005), HRCC Decision N2003/02/0329, online: AHRCC <http://www.albertahumanrights. ab.ca/HalterLes051605Pa.pdf> [Halter].

Ibid. at para. 135.

Ibid. at para. 139.

2003 ABQB 342, 336 A.R. 343 [Elizabeth Métis].

Ibid. at paras. 2, 31, 33.

Ibid. at paras. 34-35, citing L'Heureux-Dubé J. in Quebec, supra note 24 at para. 46.

Ibid. at para. 42.

Alberta (Human Rights and Citizenship Commission) v. Elizabeth Métis Settlement, 2005 ABCA 173, 367 A.R. 142 at para. 8. 
(BCHRT) decision of Middlemiss v. Norske Canada Ltd. dealt with a workplace alcohol and drug policy that mandated automatic termination for anyone found in possession of alcohol or drugs while at work. ${ }^{59}$ The Tribunal found that Mr. Middlemiss, an employee who had been terminated for drug possession, failed to establish perceived disability on the part of his employer or the policy itself. ${ }^{60}$ The fact that the Tribunal in Middlemiss put the onus on the employee to establish perceived disability is directly contrary to the decision in Halter, where the Tribunal put the onus on the employer to determine whether a dependence was present.

Similarly, in Milazzo v. Autocar Connaisseur, which dealt with random drug testing in the transport industry, the panel also declined to find perceived disability. ${ }^{61}$ The Tribunal in that case stated that " $[\mathrm{n}] \mathrm{o}$ one at Autocar Connaisseur knew, or cared, whether Mr. Milazzo was dependent on drugs. Indeed, there is nothing before us to suggest that anyone at Autocar Connaisseur ever turned their mind to the issue."62 These cases seem to suggest that employees must bring forward affirmative evidence of perceived disability beyond simply pointing to the consequences of the workplace policy in order to establish prima facie discrimination.

Several arbitration cases also suggest that, regardless of employer conduct, it is not open for employees to seek protection under human rights legislation unless they claim to be suffering from a disability. In Re Suncor Energy, Oil Sands and Communications, Energy and Paperworkers Union, Local 707 (Pearson), the arbitrator accepted that "the requirement to prove prima facie discrimination includes the obligation to at least assert that the person involved is a member of a protected class." ${ }^{63}$ In Weyerhaeuser v. Ontario (Human Rights Commission), a complaint made on the basis of perceived disability was dismissed since the complainant failed to assert that the employer held such a perception. ${ }^{64}$

The conflict regarding the interpretation of the concept of perceived disability has now been largely resolved by the recent Court of Appeal decision in Alberta (Human Rights and Citizenship Commission v. Kellogg Brown \& Root (Canada).$^{65}$ While applying for a job with Kellogg Brown \& Root (KBR), Mr. Chiasson took a mandatory pre-employment drug test. Although he began work while awaiting the results of the test, once it was established that he had tested positive for marijuana, he was dismissed. He filed a complaint with the AHRCC, alleging discrimination on the basis of disability. The AHRCC rejected his complaint on the basis that he was not suffering from a disability. However, this decision was overturned by the Court of Queen's Bench. The Court held that the workplace policy at issue (refusing to hire those that fail a pre-employment drug test) "exclude[s] addicted individuals

(8 November 2001), 2002 BCHRT 5, online: BCHRT <http://www.bchrt.gov.bc.ca/decisions/2002/pdf/ middlemiss_v_norske_canada_ltd_2002_bchrt_5.pdf > at para. 19 [Middlemiss].

Ibid. at para. 30 .

(6 November 2003) 2003 CHRT 37, online: Canadian Human Rights Tribunal (CHRT) <http://www. chrt-tcdp.gc.ca/aspinc/search/vhtml-eng.asp?doid=946\&lg-=_e\&isruling=0> [Milazzo 2003].

Ibid. at para. 90 .

(2004), 128 L.A.C. (4th) 48 at 71 (AGA) [Pearson Grievance], citing Imperial Oil Ltd. v. Communications, Energy and Paperworkers Union, Local 777 (Parsons Grievance) (27 November 2001), [2001] A.G.A.A. No. 102 (QL) at para. 225. (2007), 279 D.L.R. (4th) 480 (Ont. Sup. Ct. J. (Div. Ct.)) [Chornyj]. 2007 ABCA 426, 425 A.R. 35 [Chiasson Appeal]. 
on the basis of actual disability and non-addicted and non-impaired employees from employment based on perceived disability."66

This decision created significant concern among employers, as it was contrary to the "model" testing policies established by the CUPI and the COAA and threatened to significantly increase employer responsibility and costs to employees who violated these policies. However, the acceptance of “perceived disability” by the Court of Queen's Bench was overturned on appeal. The Court of Appeal stated in its decision:

The jurisprudence has extended the prohibited grounds to include instances where an employer incorrectly perceives that an employee has a prescribed disability. In this case KBR's policy does not perceive Chiasson to be an addict. Rather it perceives that persons who use drugs at all are a safety risk in an already dangerous workplace. $^{67}$

The Court of Appeal went on to state:

We see this case as no different than that of a trucking or taxi company which has a policy requiring its employees to refrain from the use of alcohol for some time before the employee drives one of the employer's vehicles. Such a policy does not mean that the company perceives all its drivers to be alcoholics. Rather, assuming it is aimed at safety, the policy perceives that any level of alcohol in a driver's blood reduces his or her ability to operate the employer's vehicles safely. This is a legitimate presumption. ${ }^{68}$

While the ultimate effect of Chiasson remains to be seen, it is likely that the Court's refusal to find perceived disability following a positive drug test will severely limit the ability of a non-addicted employee to make a human rights complaint against a "standard" workplace alcohol and drug policy. Chiasson has also been followed in the labour arbitration forum. Two recent decisions, Re Allied Systems (Canada) and Teamsters, Local Union 938 $(M c L e a n)^{69}$ and Suncor Energy v. Communications, Energy \& Paperworkers Union, Local 707 (Woods Grievance) $^{70}$ have rejected claims made on the basis of perceived disability.

\section{B. Reasonable Cause and Post-incident Testing}

Reasonable cause testing is alcohol or drug testing that occurs when an employer has reasonable grounds to believe that an employee is impaired by alcohol or drugs. Post-incident testing takes place following a workplace accident or "near miss," when alcohol or drug use cannot be objectively ruled out as a cause of the incident. ${ }^{71}$ Although the factual circumstances surrounding these two types of testing are different, they have been treated similarly by the courts.

Reasonable cause and post-incident testing are generally accepted as reasonable in both human rights and arbitral jurisprudence. Entrop found these forms of alcohol testing as

Supra note 33 at para. 101.

Supra note 66 at para. 34 .

Ibid. at para. 36.

(2008), 170 L.A.C. (4th) 353 (CLA).

(13 February 2008), [2008] A.G.A.A. No. 11 (QL) [Woods Grievance].

CUPI Model, supra note 4, s. 5.6. 
reasonable and permissible if they were "one facet of a larger assessment of drug abuse."72 Reasonable cause testing was specifically upheld as reasonable in Brotherhood of Locomotive Engineers (Rail Canada Traffic Controllers) v. Canadian Pacific Railway, where an employee who was arrested on drug charges was subsequently dismissed after refusing to submit to a drug test. ${ }^{73}$ Post-incident testing was upheld in Pearson Grievance, where an employee who tested positive for marijuana following a minor workplace accident was dismissed (the employee had been previously arrested on drug charges). ${ }^{74}$ Reasonable cause and post-incident testing have also been accepted by the CHRC, the AHRCC, the CUPI, and the COAA.

Although reasonable cause and post-incident testing have generally been accepted by the courts, whether such testing is upheld in a particular incident depends upon the factual circumstances surrounding the complaint. First, as required in Entrop, drug testing policies must be "one facet of a larger assessment" Halter, a post-incident drug test was ordered following a fight between two members of the complainant's work crew. The complainant was then dismissed after testing positive for marijuana. The Tribunal found that the employer lacked "reasonable cause" to order the drug test and that the test was more akin to the type of random drug test prohibited in Entrop. ${ }^{77}$ It further found that a lack of a comprehensive, inclusive policy resulted in discrimination. ${ }^{78}$ In recognition of the need for a comprehensive policy to support testing, both the Canadian Model and the CUPI guidelines require that an employee who tests positive following a reasonable cause or post-incident test be referred to a substance abuse expert to determine whether the employee is, in fact, suffering from an addiction. Both of these guidelines also require that employee assistance programs be well publicized at the job site, encouraging employees struggling with alcohol or drug issues to get help prior to failing a drug test.

Second, the decision to test must be made following an appropriate investigation. The CUPI guidelines indicate that in order to establish reasonable cause, both a supervisor and the next level of management must suspect alcohol or drug use. ${ }^{79}$ If this level of investigation were carried out, it would likely be upheld by the courts. However, if an investigation is held to be flawed, the subsequent decision to test will likely be found unreasonable. ${ }^{80}$ There is somewhat more controversy on what type of investigation is required following a decision to test "post-incident.” The CUPI and the Canadian Model merely require that a decision to test following an incident be reasonable. The policy of some employers to test following any property damage, regardless of how minor, has been upheld in some arbitral decisions. ${ }^{81}$

Supra note 39 at para. 114

2003 ABQB 165, 338 A.R. 59 [CPR].

Supra note 63.

Supra note 39 at para. 114.

Supra note 51 at para. 150 .

Ibid. at para. 137.

Ibid. at para. 150.

CUPI Model, supra note 4, s. 5.6.1; Canadian Model, supra note 4, ss. 4.4-4.5.

See Construction Labour Relations v. International Association of Heat and Frost Insulators and Asbestos Workers, Local Union \#110 (26 October 2004) GAA, online: Lancaster House <http://www.lancasterhouse.com/decisions/2004/oct/beattie-construction.pdf>, in which an employee admitted to fabricating part of the investigative report.

$81 \quad$ Fording Coal Ltd. v. United Steelworkers of America, Local 7884 (Brewer Grievance) (9 August 2002), [2002] B.C.C.A.A.A. No. 243 (QL). 
However, the prevailing view, advocated in Re Weyerhaeuser Co. Ltd. and Communications, Energy and Paperworkers Union, Local 447 (Roberto), is that following property damage, the employer is still required to engage in a balancing exercise, investigate the incident, consider the employees' involvement, and determine whether a decision to test is reasonable. ${ }^{82}$ Although the standard to require testing is not high (generally, that the accident involved the exercise of employee judgment), an automatic decision to test will be held to be unreasonable.

Finally, when a decision to test is made (for all types of testing), the manner in which the testing is carried out must be reasonable. In Roberto Grievance, damages were awarded to employees on the basis that post-incident tests (both of which were passed) were carried out in an unreasonable manner. Both employees were driven to hotels and required to provide samples with little explanation or a standardized process. ${ }^{83}$ Both the CUPI Model and the Canadian Model provide detailed guidelines on how alcohol and drug testing should be carried out. ${ }^{84}$ If these guidelines are followed, it is unlikely that the manner of testing will be found to be unreasonable.

\section{RANDOM TESTING}

Random alcohol and drug testing requires randomly selected employees to undergo testing without any reason to suspect impairment. Employers have argued that it is difficult for supervisors to determine whether employees are impaired and that random testing provides a powerful deterrent. ${ }^{85}$ However, random alcohol and drug testing policies have been the subject of controversy. Random drug testing has been consistently rejected in the arbitration context as suffering from scientific limitations and upsetting the appropriate balance between the employer's desire for safety and the employee's need for privacy. However, it has been upheld by the CHRC as reasonable in the Milazzo 2003 decision, which relates specifically to the transport industry. ${ }^{86}$ This has led some employers, including the petroleum industry (through the CUPI guidelines), to claim that such testing can be justified as reasonably necessary. In contrast, the CHRC views this decision as limited to the transport industry and continues to reject random testing as discriminatory under the CHRA. ${ }^{87}$

The first determination of whether random alcohol and drug testing constitutes discrimination under the Meiorin framework was the Entrop decision. ${ }^{88}$ As stated above, the complaint in Entrop did not deal with the random testing portion of the workplace policy. The Court of Appeal criticized the lower courts for dealing with this issue before proceeding to deal with it themselves.

(2006), (2007), 154 L.A.C. (4th) 3 at 46 (AGA) [Roberto Grievance].

Ibid. at 74-76.

CUPI Model, supra note 4, Appendix A; Canadian Model, supra note 4, Appendix A.

Imperial Oil Ltd. v. Communications, Energy and Paperworkers Union of Canada, Local 900 (Policy Grievance) (2006), 157 L.A.C. (4th) 225 at paras. 56-57 (OLA) [Imperial Oil Grievance].

Supra note 62.

Supra note 21 at 9.

Supra note 39. 
The Court found that Entrop, the complainant, had established prima facie discrimination on the basis of disability. ${ }^{89}$ The burden then shifted to the employer to establish that the policy was a BFOR. The employer satisfied the first two stages of the Meiorin test, establishing that the policy was rationally connected to the objective of promoting a workplace free of impairment (such as safety), and that it had been adopted in good faith. Most of the Entrop decision focused on the third stage of the Meiorin analysis - whether the standard was reasonably necessary.

The Court noted that while it was generally accepted that "freedom from impairment," the goal of Imperial Oil, was a BFOR, the "contentious issue is whether the means used to measure and ensure freedom from impairment — alcohol and drug testing with sanctions for a positive test - are themselves BFORs." ${ }^{90}$ In other words, the question to be determined was whether the determination of one's blood alcohol level and the determination of the presence of drug metabolites in one's system were reasonably necessary to promote the objective of a workplace free of impairment.

The Court found that random drug testing was not reasonable under the third stage of the Meiorin test because "drug testing suffers from one fundamental flaw. It cannot measure present impairment."91 The Court went on to state that a positive drug test provides no evidence that a person was impaired on the job or cannot perform the duties required by the job. ${ }^{92}$ Further, the Court noted that there are no current tests to assess the effects of drug use on performance and that drug testing has not been shown to reduce accidents or performance problems. ${ }^{93}$ In contrast, the Court found that random alcohol testing was reasonable for employees in safety-sensitive positions (so long as the employer met his or her duty to accommodate). ${ }^{94}$ This was because alcohol testing through a breathalyzer does measure current levels of impairment with reasonable accuracy. ${ }^{95}$

Entrop is significant because of the analysis that led the Court to hold that drug testing is unreasonable. The Court seems to have held that drug testing is unreasonable solely on the basis that it does not measure present impairment. If this interpretation is accepted, it may be open to employers to argue that new methods in drug testing, which measure present impairment, are reasonable.

Following Entrop, a number of cases both in the human rights and arbitration forums accepted its holding that random drug testing is not reasonably necessary. In the arbitration forum, random drug testing has been almost universally rejected as upsetting the appropriate balance between the employer need to ensure safety and employee privacy. As stated in Bantrel:

Ibid. at para. 92 .

Ibid. at para. 98.

Ibid. at para. 99.

Ibid.

Ibid.

Ibid. at para. 86.

Ibid. at para. 106. 
In its reasons the Panel also noted that the Canadian Model does not permit random testing in the sense of unannounced testing without cause of any worker on site, and concluded that this represented a reasonable balance between the rights of employers to protect the work, property, security and safety of the site while recognizing the right of personal privacy of employees. The Panel noted that the right of personal privacy has been recognized in the labour relations context. ${ }^{96}$

CPR explicitly approved Entrop's rejection of any attempts to justify random drug testing by stating that "the Entrop decision and the policy of the Canadian Human Rights Commission both properly reject as discriminatory any attempts by an employer to conduct pre-employment and random drug testing. "97 In Pearson Grievance, the arbitrator stated that "[a]rbitrators, human rights commissions and the courts have almost universally rejected an employer's ability to require random drug testing." "A8 Although the Canadian Model provides at s. 4.6 that employers may implement a "lawful" random testing policy that complies with the U.S. Department of Transportation (DOT) regulations, such a policy is unlikely to be upheld in the arbitral context (with the exception of the transport industry, as will be discussed below).${ }^{99}$ However, while random testing has been rejected when there is no prior reason to suspect alcohol or drug abuse, it may be permitted for a period of time following a failed reasonable cause or post-incident test. ${ }^{100}$

The jurisprudence under the human rights legislation has not been as clear in its treatment of random alcohol and drug testing, in part, because there are relatively few cases dealing with it. As mentioned above, Entrop prohibits random drug testing, although many interpret this to be on the basis of scientific limitations in that drug testing cannot measure present impairment. The CUPI policy authorizes random testing (subject to several caveats) at s. 5.9. ${ }^{101}$ The model urges employers to contact legal counsel and advises that random testing must be reasonably necessary due to a workplace alcohol and drug problem, a transient or unsupervised workforce, or a legal requirement for testing (as in the transport industry). If these prerequisites exist, the CUPI Model, like the Canadian Model, authorizes the implementation of a "lawful" random testing policy that complies with the U.S. Department of Transport Regulations. However, determining what constitutes "lawful” in a non-union workplace is considerably more difficult, as many of the considerations leading arbitrators to prohibit random testing (such as privacy concerns) are not addressed by human rights legislation.

The Alberta human rights decision, Halter, adopted the reasoning in Entrop and found random drug tests to be discriminatory. ${ }^{102}$ The Panel found that by administering a random blanket drug test, the employer "perceived” the employee to be disabled. However, given the limited interpretation of perceived disability by the Court of Appeal in Chiasson, the reasoning in Halter may be difficult to sustain.

Supra note 17 at para. 70 .

Supra note 73 at para. 46.

Supra note 63 at 66 [footnotes omitted].

Canadian Model, supra note 4, s. 4.6.

Supra note 70 at para. 114.

CUPI Model, supra note 4.

Supra note 51 at para. 136. 
In contrast, random drug testing has been upheld in two human rights decisions, which provide the basis for the CUPI Model's inclusion of this form of testing in its policy. However, the extent to which either of these decisions may be generalized to the "typical" workplace alcohol and drug policy is limited. The decision of Milazzo 2003 dealt with the random drug testing policy of a Quebec Motor Coach company, Autocar Connaisseur. In finding that this policy was reasonably necessary, the Tribunal focused on the specific employment context at issue. ${ }^{103}$ Namely, the Tribunal noted the lack of supervision of bus drivers for long periods of time while on the road, and the fact that positive drug tests, while not indicating impairment, serve as a "red flag" to identify drivers at greater risk of accident. ${ }^{104}$ Based on these factors, the Tribunal concluded that random drug testing was reasonably necessary. ${ }^{105}$ The Tribunal went on to add that the policy was also reasonably necessary because Canadian bus drivers (and truckers) who enter the U.S. are subject to intensive drug testing regulations under the American legislative policy. ${ }^{106}$ This policy does not allow drivers who have not passed a random drug test to cross the border. Because the Tribunal in Milazzo 2003 found that all employees of Autocar Connaisseur had the potential to cross the border, it found that the company would suffer undue hardship if it could not comply with the American legislative requirements. ${ }^{107}$

There has been controversy over the proper interpretation of this case. The CUPI, in the legal opinion included within the CUPI Model, asserts simply that Milazzo 2003 "authorize[s]" random alcohol and drug testing and is in conflict with Entrop. ${ }^{108}$ In contrast, in the last publication of their policy on alcohol and drug testing, the CHRC asserts that Milazzo 2003 is a necessary exception to the general principle, because of the need for transport companies to comply with American legislation. ${ }^{109}$ An analysis of the Milazzo 2003 case itself seems to support the position that the case is simply in conflict with Entrop and does not carve out a special exception. The Court lists the lack of supervision, the cost, and the fact that positive drug tests are a red flag and then states: "[f]or these reasons, we find that Autocar Connaisseur's drug testing policy is reasonably necessary." 110 The Court then goes on to cite the American legislation as "one further reason." 111 Although not settled, this language does not seem to support the CHRC's assertion that the American legislation formed the basis of the Milazzo 2003 decision. In contrast, in arbitral jurisprudence, the testing required in the transport industry to comply with American regulations has been held to be a "special" exception to the broader rejection of random testing. ${ }^{112}$

Random drug testing was also upheld in the Elizabeth Métis decision. ${ }^{113}$ The settlement had voted to implement an alcohol and drug testing policy, which included random drug testing, that would cover settlement employees. This policy was reviewed on its merits at the

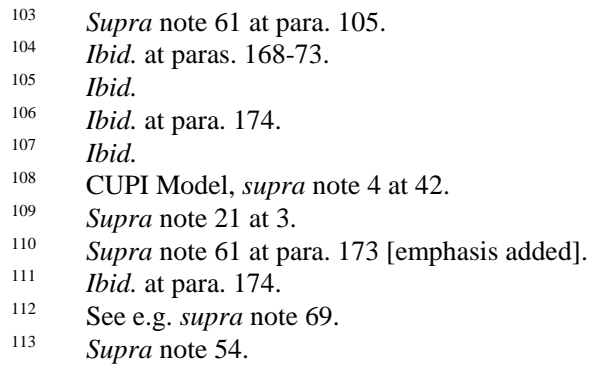


trial level, where random drug testing was found to be reasonably necessary. However, this decision was quashed at the appeal level, since the threshold issue of whether the policy applied to the complainants was not considered. ${ }^{114}$ The trial level decision's approval of random drug testing as reasonably necessary was not addressed in the appeal decision. Thus, Elizabeth Métis is not an authoritative judgment. Nevertheless, the CUPI guidelines argue that the reasoning outlined at the trial level should be considered persuasive. ${ }^{115}$

However, two factors exist that limit the extent to which Elizabeth Métis can be analogized to the employment context. First, the objective of the policy in issue was not solely to increase safety, as is typically the objective of workplace policies, but also to ensure that the employees of the settlement served as role models for the community. The Court accepted that the Elizabeth Métis settlement was a small rural native community with few jobs available. ${ }^{116}$ Further, it accepted that substance abuse was a serious problem within the community and that there was concern within the community that settlement employees were themselves substance abusers. ${ }^{117}$ The Court explicitly stated that "[t]he situation might well differ in a larger urban area where the actions of an individual person are less likely to be noticed by the community at large, and where job availability is such that those occupying municipal clerical positions are not held in especial esteem."118 It is doubtful that the situation facing most Alberta employees, particularly those employed within the oil and gas industry would be considered analogous to that of the residents of the Elizabeth Métis settlement. In the arbitration context, even when drug use in the workforce is established, random drug testing has been rejected. Pearson Grievance states that "the mere fact that drug use is a common problem among employees is not sufficient by itself to justify requiring any particular employee to undergo drug testing."119 This, statement indicates that the Elizabeth Métis decision is of little persuasive value in the corporate context.

Thus, while random alcohol testing has been found to be reasonable, the law regarding random drug testing is uncertain. Random drug testing has consistently been held to be unreasonable in the arbitration context. In the human rights context, Entrop and Halter unequivocally state that random drug testing is not reasonable. However, these cases both rest on the notion of perceived disability - a concept whose utility to employees has been curtailed by Chiasson. Milazzo 2003 is in conflict with these decisions, and this conflict does not seem to be reconcilable by pointing to the differing American legislative standards. The extent to which Elizabeth Métis conflicts with Entrop is unclear, because although it upholds a random drug testing policy, it does so for an objective that has never been asserted in a corporate workplace (employees as role models) and in a unique context. Thus, despite the CUPI's reliance on Milazzo 2003 and Elizabeth Métis to support its random drug testing policies, uncertainty about their legality in non-union environments remains. 


\section{Advances in Drug Testing Technology}

Recent advances in drug testing technology may alter the legal ability of employers to engage in random testing, as new methods of testing begin to measure present impairment. In Imperial Oil Grievance, the employer adopted a random alcohol and drug testing policy. Unlike the method of testing that had been struck down in Entrop (urinalysis), the new policy relied on oral fluid drug testing to measure current impairment by marijuana. On the basis of expert evidence, the Panel accepted that oral fluid drug testing did accurately measure current marijuana impairment. ${ }^{120}$ The Union challenged the alcohol and drug policy on the basis that it was an intrusive invasion of employee privacy, that no alcohol or drug problem existed within the workplace, and that prevailing jurisprudence had established that random testing was illegal.

The employer responded that the policy represented a fair balance between employee privacy and the need to provide a safe work environment. The employer pointed to the deterrent effect of the policy. Finally, the employer argued that prior jurisprudence was not relevant, as, unlike in Entrop, the technology being utilized was able to establish present impairment.

The Panel held that random drug testing was not reasonable. ${ }^{121}$ In doing so, they focused primarily on the need to balance the employer's interest in safety with the employee's privacy rights. They also focused on Canadian values and the importance placed on human dignity and privacy. The Panel also noted that, while the drug test does measure current impairment, unlike a breathalyzer, it cannot do so immediately. Therefore, the test was not being administered to address immediate safety concerns, but to catch employees who violate the policy. However, the Panel went on to note that it would have grave concerns even if a drug test was developed that immediately measured impairment, except in exceptional circumstances (such as the existence of an out-of-control drug culture). ${ }^{122}$

The impact of this decision is difficult to determine. It seems to counter the prevailing interpretation of Entrop and to indicate that the inability of drug tests to show present impairment is not the sole reason they have been found to be unreasonable. Therefore, employers making use of oral fluid technology may still find their policies struck down, particularly in a unionized workforce. However, the extent to which the same will be true in the context of a human rights complaint is unclear. Human rights tribunals are not the appropriate forum to address privacy concerns, which appear to have formed the primary basis for the Imperial Oil Grievance decision. It is possible, therefore, that a similar policy may be upheld following a human rights complaint. Additional jurisprudence will be required before it is possible to determine whether the courts will accept this form of random drug testing. At this time, neither the Canadian Model nor the CUPI Model authorizes oral fluid drug testing. The CUPI notes that saliva is not dealt with because concentration standards have not yet been standardized, nor is it recognized by the American legislation that forms 
the basis of their testing procedure. ${ }^{123}$ As such technology gains greater acceptance, future jurisprudence on its use is likely to provide greater clarity about whether it is a legally permissible means of random drug testing. Permitting such testing seems consistent with the analysis in the Entrop decision.

\section{E. PRE-EMPloyment DRUg Testing}

Pre-employment drug testing is another area of significant legal uncertainty. Despite this, such testing is common within the petroleum and other industries. ${ }^{124}$ Pre-employment drug testing was, like random drug testing, rejected as reasonably necessary in Entrop as it "does not show future impairment or even likely future impairment on the job, yet an applicant who tests positive only once is not hired." ${ }^{225}$ Pre-employment drug testing was also subsequently rejected in obiter comments in the CPR and Pearson Grievance cases. The Milazzo 2003 case also addressed pre-employment drug testing, stating that "employers are not entitled to automatically withdraw offers of employment, without first addressing the issue of accommodation.”126

The Chiasson decision dealt specifically with pre-employment drug testing. At the Queen's Bench level, it was held that pre-employment drug testing failed the "reasonable necessity" portion of the Meiorin test. ${ }^{127}$ However, as discussed above, this finding was overturned on appeal because Chiasson was not suffering from a disability and, therefore, did not fall under a protected ground of the HRCMA. The Ontario Human Rights Commission also concluded that there was no discrimination on the basis of perceived disability in Chornyj, where a prospective employee was not hired after testing positive for marijuana and having initially denied using drugs. ${ }^{128}$

While further jurisprudence is necessary to clarify this issue, it is likely that preemployment drug tests will continue to be upheld. Given that the Alberta Court of Appeal in Chiasson held that there was no discrimination and that a refusal to hire employees that fail a pre-employment drug test was a result of a (reasonable) perception that people who use drugs at all are a safety risk in a hazardous environment, it will be difficult for a prospective employee to argue that similar action by an employer constitutes discrimination in his or her case. This is particularly true given that most employers follow a standardized procedure, as set out in the CUPI guidelines. It is also not open for prospective employees applying for union positions to grieve that they were not hired, as, since they have not yet been hired, they are not yet union members.

CUPI Model, supra note 4 at 7, n. 3 .

Tom Barrett, “Alberta ready to push for workplace drug testing” Edmonton Journal (3 June 2004) A1. Supra note 40 at para. 103.

Supra note 61 at para. 187.

Supra note 33 at paras. 131-32.

Supra note 64. 
The Canadian Model does not address pre-employment drug testing (although it does not prohibit it). The CUPI guidelines do allow for pre-employment testing, indicating at 5.7.2(a) that

[e]mployers should require that applicants for safety-sensitive positions submit to alcohol and drug testing under 6.0 as part of the job application process.

The guidelines do go on to provide some degree of accommodation, indicating:

(b) If an employer conducts conditional-offer testing and declines to offer employment to an applicant who has tested positive for levels of alcohol or drugs ... the employer must:

(i) advise the applicant that the positive test result does not preclude the applicant from reapplying in the future, and

(ii) advise the applicant that in the event of a new application for employment, the positive test result will not affect that future application and consideration for employment, and

(iii) provide the applicant with a list of available treatment facilities for alcohol and drug dependency if the applicant wishes to take advantage of treatment services at the applicant's expense. $^{129}$

Given the prior jurisprudence, even if a prospective employee was addicted and discrimination was found (which, as stated above, is unlikely), such measures would likely constitute sufficient accommodation.

\section{F. Pre-AcCess Testing}

In addition to requiring pre-employment testing, many employers (including the majority of oil sands owners) require pre-access testing of contractors entering their work sites. Both the Canadian Model and the CUPI Model allow for pre-access testing when it is required by the owner of the site to be accessed. ${ }^{130}$

Pre-access testing was upheld in Bantrel. ${ }^{131}$ Such testing was found to be permissible under the collective agreement and not in violation of the human rights legislation. The Panel held that the testing was justified in the context of the work site (where alcohol and drug use was a known problem), that the nature of the testing was distinct from random testing, and that it was consistent with the significant safety risks. ${ }^{132}$ The ruling was subsequently upheld by the Court of Queen's Bench. The Panel also held that there was no violation of the human rights legislation because the discrimination, if any, was imposed by the owner who required the testing, and not the employer; the absence of automatic termination raised doubts about whether the policy was prima facie discriminatory, and if it was, the Meiorin test was met. ${ }^{133}$

129 CUPI Model, supra note 4 at 5.7.2(b).

$130 \quad$ Ibid. at 5.10; Canadian Model, supra note 4, s. 4.7.

131 Supra note 17.

$132 \quad$ Ibid. at para. 72.

133 Ibid. at paras. 117-24. 
This case was decided prior to the release of the Court of Appeal's decision in Chiasson, which supports the conclusion that such policies are not prima facie discriminatory.

\section{G. THE EXTENT OF THE EMPLOYER'S OBLIGATIONS TO EMPLOYeEs WHO Test POSITIVE}

Even if testing that occurred pursuant to a workplace policy is found to have been legal, employers still have legal obligations to those employees who test positive. These obligations are considerably different in the human rights and arbitration contexts.

With regard to human rights, employers are only required to accommodate employees that fall within the protection of the human rights act and are, in fact, suffering from the disability of addiction. As discussed above, some non-addicted employees have attempted to argue that they have been the victims of a "perceived disability," however, following Chiasson Appeal, this argument is unlikely to be accepted.

To determine whether an employee is, in fact, addicted, both the CUPI Model and the Canadian Model require that the employee be referred to a substance abuse professional. If the substance abuse professional determines that the employee is not addicted and the employee does not assert that he or she is addicted, then the employee is not protected by the human rights act under the grounds of disability. The employer can then discipline the employee (although, as will be discussed, there may be limits to the discipline that can be imposed).

If an employee is found to be addicted, the employer must justify any disciplinary action as a BFOR. In order to do this, the employer must establish that the duty to accommodate has been fulfilled or, alternatively, that the employee cannot be reasonably accommodated before the point of undue hardship. ${ }^{134}$ Although an employer may "just prefer to fire [the workers],"135 they must be accommodated to the point of undue hardship.

The duty to accommodate is inherently fact specific and a determination of what is appropriate requires an examination of the circumstances. Larger employers seem to have a greater duty to accommodate, because it is more difficult to establish that specific actions will result in "undue" hardship for the employer when the company is "sizeable and financially sound.”" This contextual specificity makes it difficult to establish general principles regarding the exact nature of the duty to accommodate. Furthermore, little guidance has been offered by the courts. Decisions such as Entrop state that an employer has failed to meet a duty to accommodate, but do not go on to establish what types of behaviour would have met such a duty. ${ }^{137}$

It does seem clear that automatic termination as a result of a positive alcohol or drug test, while often considered desirable by employers, will not meet the test of reasonable 
accommodation. ${ }^{138}$ Such a decision is simply inconsistent with the principles of Meiorin. Indeed, the 2005 CHRT decision, Milazzo v. Autocar Connaisseur, goes a step further, and states that "last chance agreements," which purport to give the employer the right to fire an employee who has already been accommodated once as a result of a failed drug test, are unenforceable. ${ }^{139}$ It is important to note that Milazzo 2005 is not asserting that the firing of an employee after a second failed drug test will never be a BFOR. ${ }^{140}$ Rather, Milazzo 2005 emphasizes the need to examine each case on its facts, rather than stringently applying a universal standard.

Some of the duties that have been advocated in the case law include automatically referring to a medical professional to recommend appropriate and relevant forms of rehabilitation, ${ }^{141}$ moving the employee to a different position, ${ }^{142}$ or reinstating the employee following rehabilitation. Follow-up testing after initial accommodation has been accepted by the courts as appropriate. ${ }^{143}$ The courts have rejected employer policies that provide for accommodation only when the employee approaches the employer prior to a failed drug test. Milazzo 2003 states that such policies do not recognize the significant role that denial plays in substance abuse. ${ }^{144}$ This view is quoted with approval in Halter. ${ }^{145}$

The duties on employers to accommodate seem to lessen when the employee refuses to undergo a test or accept rehabilitation, since "[i]f an employee elects not to expressly disclose the nature and type of her disability, and does not take the test to provide test results to aid in a diagnosis, it would be difficult to fault an employer for failing to offer appropriate drug or alcohol treatment."146

The CHRC policy advocates referral to a substance abuse professional and reinstatement after rehabilitation. This policy rejects automatic reassignment, urging a contextual determination. It recognizes that in some situations, follow-up testing may be justified, and urges that this determination be made by a rehabilitative expert. These recommendations are largely accepted in the CUPI Model and the Canadian Model, which indicate that automatic termination is not an appropriate response to a positive alcohol or drug test. ${ }^{147}$ Instead, they state that all employees testing positive for alcohol or drugs will be referred to a "substance abuse expert" for an assessment and development of a treatment program. ${ }^{148}$ However, the guidelines go on to state that the "failure by the employee to attend the assessment or follow the recommended treatment program may be cause for termination." 149 While termination eng.asp?doid=947\&lg=_e\&isruling=0> at para. 34 [Milazzo 2005].

Ibid. at para. 35 .

Supra note 51 at para. 149.

Supra note 61 at para. 184.

Supra note 39 at para. 129.

Supra note 61 at para. 183.

Supra note 51 at para. 149.

Supra note 51 at para. 73.

CUPI Model, supra note 4 at 8.1.1.

Ibid., 8.2.2.

Ibid., 8.2.5. 
may be warranted in this situation, this provision seems insufficiently sensitive to individual situations to be upheld by the courts.

For non-addicted employees who do not fall under the protection of a human rights act, discipline following a failed drug test may still be grieved on other grounds. For non-union employees, as in all common law terminations, the obligation is on the employer to establish just cause for dismissal, typically through a demonstration that progressive discipline has been used. Termination following a failed drug test may be found insufficient to meet the just cause requirements.

In the union environment, employers who have adopted the Canadian Model often require employees who have failed a drug test to sign a "last chance" agreement, stipulating that they will submit to random testing and that following an additional failed drug test they will be dismissed. Such agreements have often been grieved by employees. In the recent Woods Grievance decision, the arbitrator reviewed prior jurisprudence and concluded that "last chance agreements" were unreasonable when they required mandatory termination without consideration of individual circumstances. ${ }^{150}$ This is similar to the comments made in Milazzo 2005. Although termination may be reasonable, especially in the case of prior failed tests, the employer must demonstrate that they considered the circumstances as opposed to following a checklist. ${ }^{151}$

\section{LEGISLATION}

Despite the complexities involved in the introduction of workplace alcohol and drug testing policies, there is no federal or provincial legislation in Canada that deals with this issue. This is in contrast to the extensive regulations that have been passed in the U.S. ${ }^{152}$ Such regulations deal not only with substantive matters, such as when testing is appropriate, but also with procedural matters, such as the collection of samples, approved methods of testing, "cut-off” quantities of alcohol and drug metabolites, and approved laboratories. ${ }^{153}$ Both the CUPI Model and the Canadian Model adopt large portions of the U.S. DOT regulations to govern the Canadian procedure.

Given the prevalence of workplace alcohol and drug policies in some Canadian industries, I believe that legislative guidance in this area would be of value in Canada. First, it would allow Canadian legislatures to clearly articulate the appropriate balance between an employer's obligation to ensure safety and an employee's right to privacy. Upon reading the complaints of employees, both in the human rights and arbitral contexts, it is clear that many employees view testing, particularly random testing, as invasive and a violation of their privacy. This concern can be directly addressed in the arbitral context. As discussed above, many arbitral decisions directly discuss privacy concerns and the need to achieve an appropriate balance, emphasizing the importance of privacy as a fundamental Canadian value. For the majority of Canadians who work in a non-union environment, however, the

\footnotetext{
$150 \quad$ Supra note 70 at para. 97.

$151 \quad$ Supra note 82 at 54.

15249 C.F.R. $\S 40$ (1991) [DOT regulations].

153 Ibid., pts. D, E, F.
} 
impact of privacy concerns is much more limited. Such employees may choose to make a complaint under the HRCMA. However, this legislation only covers the minority of employees suffering from an addiction, or those perceived to be - which, given the recent Court of Appeal decision in Chiasson Appeal, will be unlikely to include non-addicted employees governed by a "model" plan. Even if an employee does fall under the jurisdiction of the HRCMA, this legislation was not drafted to address privacy concerns and is ill-suited to do so. Although there is privacy legislation in Canada, most employees will have consented to the workplace policy as a condition of their employment. Therefore, this issue, which is often cited by employees and by arbitrators as fundamental to workplace alcohol and drug testing, is largely unaddressed for employees in a non-unionized workplace.

Second, workplace alcohol and drug testing programs carry with them a host of scientific and procedural considerations that are not well-suited to resolution by the courts. In the U.S., the DOT regulations for employee drug testing establish a detailed set of procedures governing the collection of samples, approved methods of testing, "cut-off” quantities of alcohol and drug metabolites, and approved laboratories. ${ }^{154}$ No such legislation exists in Canada - for the most part, model policies adopt the DOT regulations and test in DOTapproved laboratories. These procedural considerations require medical and industry expertise, and they mandate a comprehensive and detailed approach. For this reason, they are not well-suited to be addressed through jurisprudence and would be governed best by legislation. Legislation would also be helpful in addressing scientific advances. For example, oral swab drug testing could be approved through consultation with the industry and experts, rather than implemented by an employer who must remain uncertain of its legal status until it is tested in the courts.

\section{A. Content OF LEgISLATION}

Based on the analysis of case law outlined above, I believe that valid legislation dealing with alcohol and drug policies could include reasonable cause and post-incident testing, and pre-employment testing, so long as such testing is demonstrated to be reasonable and is introduced in conjunction with a broader alcohol and drug program. Whether random drug testing should be permitted is an issue that would need to be determined after industry and employee consultation. Although it has largely been rejected in the union context, in my opinion, when dealing with a non-unionized workplace, current case law indicates that it is legal to randomly test employees, so long as those suffering from an addiction are subsequently accommodated. The ensuing privacy issues should be dealt with by the government. The significance the government gives to the privacy of employees will determine whether random alcohol and drug testing is appropriate. However, even if legislation is passed that indicates that random testing is appropriate, given past arbitral jurisprudence, it is likely to continue to be prohibited in union environments under the collective agreement or as beyond the legitimate use of management rights.

In addition to authorizing broad areas of testing, it will also be necessary for legislation to provide greater clarity about the obligations of employers who choose to implement these programs. Case law indicates that a testing policy must be part of a "comprehensive, 
inclusive policy which has a range of components." ${ }^{\text {"155 }}$ Legislation allows the government to provide greater clarity to employers about what constitutes an acceptable "broader” program. Such a program may include the availability of counselling, access to educational information, or workplace seminars on alcohol and drug abuse. The most effective and appropriate model programs can be developed through consultation with the industry and experts in the area of substance abuse.

Legislation can also serve to clarify the proper procedures to be used in an alcohol and drug testing program. Some of the concerns raised by this lack of legislative or judicial guidance include a lack of knowledge about appropriate collection and laboratory procedures, the lack of Canadian certification of laboratories, the failure of employers to use medical review officers to analyze results, ${ }^{156}$ and the use of "Point of Collection Testing" (POCT), a drug screening test performed by the employer outside of a certified laboratory. ${ }^{157}$ POCT results are verified at the discretion of the employer, leading to concerns about biased or inaccurate interpretations. In large part, much of the procedural aspects of workplace alcohol and drug testing legislation could be modelled on the U.S. DOT regulations, which outline appropriate procedures in considerable detail and reject POCT. ${ }^{158}$ It would be prudent to subject the procedural aspect of legislation to a mandatory review every few years in order to implement new forms of testing (such as oral swab collection) that the government deems to be effective and to provide guidelines about how this testing should be used in the workplace.

Legislation also offers the opportunity to more clearly define other aspects of the testing process. For instance, the model policies mandate that employees testing positive meet with a "substance abuse professional" to determine whether addiction is present, therefore making an employee subject to human rights legislation. Providing a standard set of qualifications for a "substance abuse professional" will give guidance to employers and ensure that employee rights are adequately safeguarded.

\section{B. BENEFITS OF LEGISLATION}

Perhaps the most significant benefit of legislation is certainty for both employers and employees. Incremental development of case law, scientific advances, and variations between workplaces all lead to uncertainty about the legal obligations of an employer seeking to implement a workplace alcohol and drug program. Uncertainty about whether a complaint will be upheld also discourages employees from challenging such programs. Legislation would provide a firm foundation for employer policies and would inform employees of their legal rights.

There has been considerable pressure on government to implement such legislation. In the Milazzo 2003 decision, all of the major witnesses cited in the decision, including the president of the company whose policy was challenged, the president of the trade association

\footnotetext{
$155 \quad$ Supra note 51 at para. 150.

156 Supra note 12.

157 CUPI Model, supra note 4, Appendix A at 23.

$158 \quad$ Supra note 152.
} 
of motor coach operators in Canada, and an expert in alcohol and drug policy development, "expressed frustration with the Canadian government's actions." ${ }^{\text {"159 }}$ The decision of the court stated that "[the federal Department of Transport] opted not to involve itself in the issue, leaving Canadian bus companies to their own devices in trying to figure out how best to deal with American legal requirements, while still complying with Canadian human rights law.”160

This frustration is shared outside the transport industry. Bob Blakely, president of the Building and Construction Trades Council, states that "[t]here is an urgent need for 'what amounts to a clear set of rules, exactly what can be done, and what can’t be done."”161 Tina Giesbrecht, a Calgary lawyer with McCarthy Tétrault LLP, is quoted in the Canadian Occupational Health and Safety News, stating: “"The safety concerns raised by substance abuse and people who are under the influence at work cannot be ignored by government or by employers'.... Any Alberta legislation related to drug testing may help guide employers on this complicated issue." 162 In the past, even the Alberta government has recognized the demand for legislation on this issue, with Clint Dunford, former Minister of Human Resources and Employment for Alberta, stating:

\footnotetext{
Although some companies have already taken action [implementing alcohol and drug testing programs], they realize they are on somewhat shaky ground legally and that's where government comes in.... "I think that has to come from the province. We're the ones who hold the legislation on workplace health and safety and we're the ones who hold the legislation on human rights. I think it's up to us to provide the guidance.”163
}

This statement was met with support from employers, with Suncor, one of Alberta's largest oil companies, stating “[r]ight now we rely on case law for our drug and alcohol testing policy and we'd like to see legislation that would more clearly define human rights and health and safety issues."164

Certainty offers significant advantages to employers, as it would save the costs involved in monitoring inconsistent legal decisions and responding with changes to their workplace policy. As Giesbrecht points out, "legislation on drug testing might aid employers who are not in the position to follow the ever-expanding file of cases."165 Employers spend a significant amount of money and time developing such programs, and a new case that significantly alters the existing framework would prompt a need to begin the consultation and policy development program again. Further, the issue of new case law developments is particularly problematic in the employment context because, aside from issues of cost, workplace alcohol and drug policies must be accepted by each individual employee as part of his or her employment contract. Thus, when a policy changes, the employer must get existing employees to agree to incorporate the new policy into their employment contract. This is costly and time consuming, as it requires the consent of existing employees, or, if

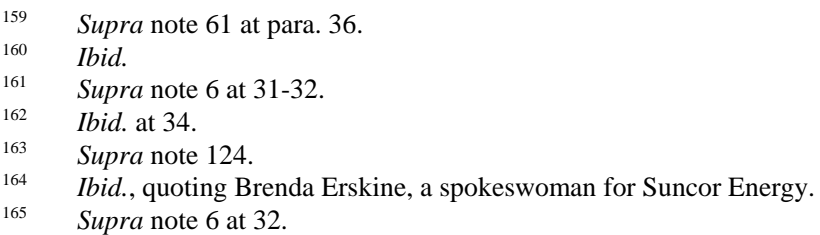


employees refuse to consent, the use of a sufficient notice period. ${ }^{166}$ The consistency and stability of a legislative framework would offer great advantages in the employment context.

Second, legislation is also advantageous because it is comprehensive. As stated above, there are procedural controversies in the alcohol and drug testing context that have not been addressed by the courts. Issues such as laboratory testing, cut-off concentrations, and the role of medical review officers are not conducive to being resolved through a principled legal analysis. Legislation gives the government an opportunity to ensure that such tests are being conducted in a consistent manner that respects the employee's human rights. Legislation could also be reviewed to ensure that new testing methods were approved if they proved to be effective. Such review is important. As Dr. Harold Hoffman states, the "lack of guidance and clarity around the issue of testing leads to approaches that are ill-conceived or wrongly applied." 167

The final advantage of legislation is that it would apply universally to all employers wishing to implement an alcohol and drug testing program. The Canadian Model and the CUPI Model, despite some conclusions that may be legally uncertain, represent a comprehensive approach to provide clear and consistent guidance to employers. However, such industry policies are limited, since employers have no obligation to adopt them, and they do not apply outside of the specific industry that they govern. Many outside employers lack the sophistication to develop such programs. As Dr. Hoffman states: "without a formal standard policy that can be applied across the board, industries and individual companies are left to their own devices, making ad hoc policies with little or no muscle to protect worker and public safety."168

By implementing legislation that deals with workplace testing policies, the government would have an opportunity to provide guidance on the values that should underlie such testing. The relatively recent introduction of provincial privacy legislation seems to be an indication that this is an area of priority for the government. Legislation offers an opportunity for the government to clearly indicate if and how privacy issues will affect workplace testing policies. If it concludes that protections are warranted, legislation may be able to provide some additional protections to non-union workers and adopt some of the principles articulated in the arbitration context.

\section{Legislative Challenges}

Notwithstanding its benefits, the introduction of legislation in this area offers a number of challenges. Since it would cover a variety of workplaces and deal with scientific testing methods, the drafting of acceptable legislation would require consultation with the industry, employees, substance abuse professionals, and drug testing experts. Arriving at a consensus about an appropriate policy would likely be difficult. Scientific advances in testing methods would require that legislation be reviewed periodically. However, the model policies 
developed by the CUPI Model and the Canadian Model provide a valuable starting point for legislative development.

An additional challenge would be the fact-sensitive nature of challenges to workplace alcohol and drug policies. When employees test positive, the appropriate response depends heavily on the circumstances. Although legislation can provide some guidance (as evidenced in the model policies), discretion of the employer will continue to be required. This, of course, prevents absolute certainty about the legality of a particular response in a particular situation.

Finally, any legislation would also be open to a Charter challenge. The Charter governs all government action, including the enactment of legislation. ${ }^{169}$ Initial Charter challenges to alcohol and drug testing legislation would likely take place under s. 15 of the Charter, which states:

(1) Every individual is equal before and under the law and has the right to the equal protection and equal benefit of the law without discrimination and, in particular, without discrimination based on race, national or ethnic origin, colour, religion, sex, age or mental or physical disability.

(2) Subsection (1) does not preclude any law, program or activity that has as its object the amelioration of conditions of disadvantaged individuals or groups including those that are disadvantaged because of race, national or ethnic origin, colour, religion, sex, age or mental or physical disability. ${ }^{170}$

The purpose of this section is "to prevent the violation of essential human dignity and freedom through the imposition of disadvantage, stereotyping, or political or social prejudice, and to promote a society in which all persons enjoy equal recognition at law."171 To establish discrimination under s. 15, it is necessary to demonstrate that (1) a distinction has been made on the basis of one or more personal characteristics; (2) that this distinction was based upon an enumerated or analogous ground of discrimination; and that (3) the distinction results in a discriminatory purpose or effect. ${ }^{172}$ If discrimination is established under s. 15 , it may be justified under s. 1 of the Charter by demonstrating that the legislation was enacted for a pressing and substantial objective, and that it is proportional. Proportionality is shown by demonstrating (1) a rational connection with the objective; (2) minimal impairment (that the legislation infringes upon rights to the least amount possible); and (3) that the benefits of the legislation clearly outweigh its deleterious effects. ${ }^{173}$

Since no legislation dealing with alcohol and drug testing has been enacted in Canada, there has not been a prior s. 15 analysis in this area. However, the court has affirmed that the purpose, meaning, and content of equality rights in both the human rights acts and s. 15 of the Charter are similar. ${ }^{174}$ As the Supreme Court of Canada stated in Egan (which was later adopted in Law), s. 15 rights are essentially about protecting human dignity. ${ }^{175}$ This is the

RWDSU v. Dolphin Delivery Ltd., [1986] 2 S.C.R. 573 at 596.

Charter, supra note 5, s. 15.

Law v. Canada (Minister of Employment and Immigration), [1999] 1 S.C.R. 497 at para. 51 [Law]. Ibid.

R. v. Oakes, [1986] 1 S.C.R. 103 at 138-40.

Supra note 33 at para. 55, citing Egan v. Canada, [1995] 2 S.C.R. 513 at para. 39 [Egan].

Egan, ibid.; Law, supra note 169. 
same underlying purpose as one of the human rights act. Further, as the Trial Court in Chiasson pointed out, "human rights legislation [has been] interpreted in conformity with Charter rights and values." ${ }^{\text {" }}$ Given this recognition of the need for consistency between the Court's s. 15 analysis and human rights analysis, it is likely that any provincial legislation that is in conformity with the HRCMA and the CHRA will also be upheld under a s. 15 analysis.

Given the invasive nature of alcohol and drug testing, there is a possibility that legislation could be challenged under s. 7 of the Charter, as a violation of security of the person. ${ }^{177}$ However, such a challenge seems unlikely to succeed given the past jurisprudential focus on equality rights, and the fact that alcohol and drug tests, while arguably invasive, are, as the employment relationship itself, viewed as voluntary. The lack of challenges to such policies under provincial privacy law seems to indicate the limitations of this line of argument.

\section{CONCLUSION}

The introduction of workplace alcohol and drug policies has led to significant legal challenges for both employers and employees. Employers have developed extensive policies, only to have portions of them struck down by the court as violating human rights legislation or the governing collective agreement. Although many forms of alcohol and drug testing have been deemed acceptable in the Canadian workplace, uncertainty remains about random testing, new testing methods (such as oral swab testing), and accommodation. There is also considerable debate over the role privacy concerns should play when considering workplace testing policies.

Legislation offers the government an opportunity to clearly articulate the appropriate balance between workplace safety and human rights concerns, and to address the role, if any, that privacy concerns should play. Further, legislation would prove beneficial to both employers and employees by providing certainty, comprehensive guidance, and universal application. The government has encouraged the protection of human rights under the HRCMA, the development of safe workplace practices under the OHSA, and has identified privacy as a significant concern through its enactment of privacy legislation. Legislation dealing with workplace alcohol and drug testing would give the government the opportunity to strike the appropriate balance between these objectives, while enabling employers and employees to have a clear understanding of their rights and obligations.

Section 7 of the Charter, supra note 5 states: "Everyone has the right to life, liberty and security of the person and the right not to be deprived thereof except in accordance with the principles of fundamental justice." 